Article

\title{
Business Survival and the Influence of Innovation on Entrepreneurs in Business Incubators
}

\author{
Manuel Octavio Del Campo Villares ${ }^{1}$, Vanessa Miguéns-Refojo ${ }^{2}$ \\ and Francisco Jesús Ferreiro-Seoane ${ }^{3, *}$ \\ 1 Faculty of Economics and Business, Department of Applied Economics, University of A Coruña, \\ 15071 Galicia, Spain; moctadcv@udc.es \\ 2 University of Santiago de Compostela, 15782 Galicia, Spain; vanessamigensrefojo@hotmail.com \\ 3 Department of Applied Economics, University of Santiago de Compostela, 15782 Galicia, Spain \\ * Correspondence: franciscojesus.ferreiro@usc.es; Tel.: +34-629-88-19-09
}

Received: 29 June 2020; Accepted: 27 July 2020; Published: 31 July 2020

\begin{abstract}
One of the objectives of this article is to study how innovation influences the results of entrepreneurs located in business incubators. The other objective is to examine how the training of entrepreneurs contributes to creating companies with high sustainability rates over time that are wealth generators in society. To achieve these objectives, entrepreneurs in business incubators in Spain were identified along with their level of training, their experience in business management, how much employment they have generated, their survival rate and the annual accounts (where economic, financial, and management information on the companies is collected). In turn, they were sent a questionnaire that allowed us to classify them by their degree of innovation. The techniques used are independent sample statistics that apply the Levene's test, the analysis of the balance sheet, the income statements, and management indicators. This study concludes that, from the selected sample, $83.3 \%$ of the entrepreneurs established in business incubators in Spain have university training, and $64.2 \%$ prefer the branches of science, with 7.75 years of business experience, which favors business survival (100\% in the seventh year of life) and the creation of qualified employment. All this favors the sustainability of the productive and business model which, being more intensive in knowledge and $R \& D$, becomes more competitive in the market. On the other hand, there are no significant differences regarding the economic results, nor in the management indicators among the entrepreneurs of the incubators according to their degree of innovation. The value of research lies in the importance of studies on the relationship between innovation, training, and wealth-generating sustainability in incubators in today's knowledge economy.
\end{abstract}

Keywords: business incubators; innovation; entrepreneurship; sustainability; survival analysis; self-employment

\section{Introduction}

In today's economy, where the market is increasingly competitive, knowledge-intensive activities and new technologies are becoming very important as the main competitive advantage of companies. The aim of this article is therefore to examine whether innovation has a positive impact on business profitability [1] and whether the training of entrepreneurs with the help of incubators contributes to creating businesses with high survival rates [2].

The historical origin of business incubators is located in Batavia (New York, NY, USA) in 1959 [3], and spread across the United States, where there are world-famous cases, such as the Silicon Valley industrial park and the Stanford Research Park, both created by Stanford University. However, it was not until the 1970s that public action was taken on this issue through programs such as the 
Economic Development Administration (EDA) and the National Science Foundation (NSF), in the search for economic development and the creation of new sustainable companies over time. In Europe, business incubators appeared primarily in the United Kingdom as a result of the joint action of the British Steel Corporation and the European Union, which facilitated the implementation of initiatives in the establishment and support of companies, as well as the generation of new jobs [4]. Incubators play a key role in the process of economic development of communities, providing entrepreneurs with the instruments and services necessary to accelerate the growth and success of business projects [5]. Business incubators become a great support for small businesses by providing services such as networking services, capital support and training programs, and by mediating between business creation and government regulations for entrepreneurship. This is why business incubators can play an essential role in boosting small business development [6].

On the other hand, business incubators maximize the adjustment between the services they provide and the specific needs of new businesses, in addition to monitoring their performance, which allows them to detect risks and avoid mistakes [7].

It should be noted that a business incubator center is an effective method for stimulating sustainable economic growth [8] (p. 18), since it has a positive effect on social, technical, and financial indicators, and its cost of creating new jobs is six times lower than that of other types of investments.

There are more than 7000 incubator programs around the world [9]. At the beginning of the 21st century, there were 900 incubators in the US, a pioneer country in these initiatives, creating more than 19,000 companies and 245,000 jobs in a single year [10]. In the case of Europe, Germany stands out as the European country with the greatest number of incubators, followed by France and the United Kingdom [11]. In Spain, it is estimated that there are around 300 incubators, where Catalonia has the largest number [12].

Since their origin, business incubators have evolved from being just a physical space for entrepreneurs to currently being a multidisciplinary offer of services, giving rise to important changes in their operation and actions, and introducing a new concept of incubator [13]. The growing need to orient its services to an increasingly competitive market becomes evident [5].

\section{Literature Review and Conceptualization of the Business Incubator}

It is important to conceptualize what the academic world understands as a business incubator. These are facilities where spaces are temporarily made available for the undertaking of R\&D (Research \& Development) activities and which are usually located near an academic institution and/or research center [14]. Originally, incubators simply offered a physical space for companies to install and share equipment, information (on permits, patents, loans...), receive support and advice on management and marketing techniques, enjoy basic services at low cost, and find access to capital [15-17].

Business incubators are organizations that promote the creation of companies whose service extends to activities of innovation advice and training of entrepreneurs $[18,19]$. This is a development policy for generating spaces where business activities are carried out in the early stages of productive development, since technical assistance and support are provided for the establishment of the company [20]. In this way, they have become instruments of economic development and job creation $[4,21]$.

The incubators are also described as facilities created and enhanced in a specific area whose objective is the development of SME (Small and Medium-sized Enterprises) projects, usually financed by the public sector, as it is considered a contribution to local and regional development [22]. An incubator would be an institution financed largely by public funds whose objective is the creation of competitive companies with high survival rates, which allow the generation of sustainable jobs and contribute to local and regional development [23]. For this purpose, they offer a space and a set of services for a limited time (given that they are financed with public resources, it is not possible to perpetuate non-competitive companies by generating unfair competition). In short, it is concluded that business incubators contribute directly and indirectly to national development [24]. 
Small and medium-sized enterprises play a crucial role in generating economic growth, job creation, and sustainable development [25] (p. 20). For this reason, the entrepreneur, as the person primarily responsible for the survival and success of the business, must have problem-solving skills, as well as confidence in their ability to solve challenges, adaptive assertiveness, and entrepreneurial self-efficacy [25].

On the other hand, a study on the level of satisfaction with the services offered by incubators reveals that incubated businesses prioritize: collaboration between university agents and businesses, collaboration of volunteers, legal advice, increasing financial benefits to create new jobs, and engineering assistance. The study also concludes that it is important for the business incubator to be involved in both the pre-incubation phase and the incubation itself, without neglecting the post-incubation phase [26].

There is great innovation arising from the activity of business incubators [27]. Innovation is the process of integrating existing technology and inventions to create or improve a product or process [28]. Innovation represents a path through which knowledge is transferred and becomes a process, a product or service that incorporates new advantages for the market or society [29]. Innovation is an objective, goal, aspiration, pragmatic reason, value, and commitment to change [30]. The purpose of $R \& D$ is to promote the triangle: education, innovation, and research [31].

SMEs pursue innovation for market-related reasons such as meeting customer expectations or being competitive and able to stay in the market [32]. The concept of innovation is linked to the market, as it is considered the process through which intellectual capital creates a new idea that will subsequently be commercialized in a sustainable manner [33].

Innovation is the set of scientific, technological, financial, and commercial activities that allow introducing new or improved products, services, processes, and management techniques in the national or foreign market [34]. The economic dynamism of a region depends on its capacity for innovation, which is sustained by its investment effort in R\&D [35].

Access to knowledge and innovation is essential for regional development and competitiveness. In this regard, business incubators become regional development platforms integrated into a regional innovation system that can absorb exogenous knowledge [36] through links with other actors that stimulate economic activity and the local, regional, and national economy [7]. These linkages can strengthen the organization's capacity to engage in open innovation and can be formal (contracts) or informal (history, culture, or trust) [37]. Greater openness to external sources of knowledge favors open innovation and thus innovative performance, as well as facilitating information flows between companies [38].

Given that knowledge-based entrepreneurial companies are the main generators of economic growth, incubators constitute a great support for them [6], and they are an important mediating link between universities and companies [36]. Universities play a fundamental role as generators of knowledge and innovation [36], in addition to the fact that companies incubated in universities yield better results in terms of employment and sales [7]. From the point of view of the perception of incubated companies, resources related to knowledge and culture are highly valued [39].

The establishment of close links with universities enables the employment of students, which is beneficial for both parties [8]. Yet, there are other relationships that can also be beneficial to business, such as collaborating with NGOs (non-governmental organizations) in clarifying the relationship between economic innovation and sustainability [40]. New science, technology, and innovation (STI)-based enterprises can be a key way to achieve Sustainable Development Goals (SDGs). Business incubators can support this process by including SDGs among their specific objectives, developing performance monitoring systems, and coordinating with other actors through networks of information flows through which lessons learned are transferred [41].

Entrepreneurs in Spain are not interested in incorporating the capabilities necessary to face digitalization, either with their own talent or by hiring service companies [42]. Larger companies (especially medium-sized ones) with managers that have university studies carry out greater and more 
important innovation in the areas of products, processes, and management [42]. On the other hand, the percentage of SMEs carrying out innovation activities increased during 2017 [43].

There is some work on innovation linked to business development [1], such as a study which points out the positive effect of organizational innovation on company growth based on a sample of 4125 Spanish companies; or a research that concludes the existence of a correlation between competition and innovation, a study of 1347 companies in Chile [44]. Organizational learning capabilities have a positive impact on innovation performance, especially in organizations where knowledge exploitation is the main source of competitive advantage [45].

New business development is not linear, rather, it is prone to interruptions and reversals [46]. Rates of return are non-stationary increasing or decreasing rapidly as a result of an adjustment process [47]. Innovative start-ups are often seen as key drivers of innovation and the creation of new sustainable jobs [48], but due to the dual responsibility of being both new and small, they also face greater obstacles than larger, better-established firms [49]. The advantage of small and young companies is their potential for growth and job creation [50-52].

Currently, there is no reliable evidence on the effectiveness of public policies for high-growth entrepreneurship [53]. It is important, therefore, to understand when public support succeeds in promoting growth [54]. The incubators that have consumed the most resources from public administrations in Galicia between 2009 and 2013 are those that have contributed the most to revenue and are highly profitable socioeconomically in terms of business creation, employment, and sustainability over time [55].

Recent studies link innovation to aspects of competition and business development, but there is a lack of studies directly related to companies that are incubated or located in business incubators. Although there are very recent studies on regional development platforms and their link to scientific innovation, sustainable economic development or the level of satisfaction of incubated companies with the services provided by incubation centers $[8,26,36,41]$, there is thus a need for more empirical research that directly compares overlapping groups of innovative start-ups supported by an incubator with those that did not have this support, allowing for solid conclusions that inform policy on high-growth entrepreneurship [56]. It would be important to identify the most appropriate programs to promote business growth, which is a challenge when assessing the effectiveness of planned policy intervention in this regard [53,57].

\section{Objectives and Methodology}

There is a great deal of innovation in the activities developed by entrepreneurs located in business incubators [27]. In turn, business incubators are usually integrated into regional innovation systems [36]. On the other hand, there is also a need for empirical research to analyze innovation in companies supported by incubators [56]. Thus, there is an opportunity to identify entrepreneurs who have been in business incubators and classify them according to their degree of innovation as more and less radical. The first objective of this article is to analyze whether companies with a higher degree of innovation have greater business growth and better management data [1].

As business incubators play an essential role in boosting small enterprises [6] and stimulating sustainable economic growth [8], they contribute directly and indirectly to national development [24]. On the other hand, knowledge-based businesses are the main generators of economic growth, and incubators are a great support [6]. Through the "integral model of public resources," incubators create business initiatives that are sustainable over time, generating sustained wealth through the creation of businesses and jobs [2]. Therefore, the second objective is to analyze whether the training of entrepreneurs with the support of incubators contributes to creating sustainable businesses over time.

The sample taken for this research consists of companies constituted in societies with the obligation to submit annual accounts. For this purpose, the project has been supported by the Spanish Chambers of Commerce, institutions that lead business incubators in Spain [58]. 
Therefore, and in view of the aim of this article, it is necessary to analyze whether there are significant differences in the results of companies with radical innovation strategies compared to those with less intensity in such innovation that have been in the incubators of the Chambers of Commerce of Spain and to analyze sustainability over time.

The variables used for this study are classified as follows:

- Identification: name of the company, business incubator where it is or was, year of establishment of the company, legal form, Tax Identification Number, years of activity and presentation of accounts, training of the entrepreneurs, type of activity, jobs created.

- Innovation. A questionnaire was prepared to determine the degree of innovation carried out by each company, obtaining two groups: radical innovation (those that have higher values in introducing, experimenting and developing new products/services; greater release frequency, or improving the quality of existing ones) and non-radical innovation companies, (those that have lower values in the items reviewed).

- Economic and management:

- Balance sheets;

- Income statement;

- Variables of profitability, operations, structure, and per employee.

The number of companies that answered the questionnaire, allowing to indicate the degree of innovation, that were within the incubators, amounted to 30, all of which were limited companies, half of which were radical innovation companies.

The techniques used are independent sample statistics applying the Levene's test, averages, balance sheet analysis, income statement analysis, as well as different profitability, operational, and structural ratios.

\section{Results and Discussion}

\subsection{Characterization of the Companies}

The companies that answered the survey are located in 17 different incubators that belong to the Spanish Chambers of Commerce. All of them are companies that are required to present their annual accounts to the Commercial Register. In the present study, limited companies predominate (93\%) and the entrepreneur, when setting up a company, does so mainly as a limited company (73.2\%) [58]. Self-employment cannot be confused with the individual entrepreneur, since self-employment is the social security contribution regime used by employers to make contributions. Employers in limited companies are therefore self-employed, in the same way as individual entrepreneurs. The fact that they set up limited companies is an indicator of sustainability, since setting up as a company entails many more requirements, and when the entrepreneur takes this step, it is because he or she has expectations of sustainability over time. The average age of these companies is 6.7 years, taking as the last date 31/12/2018 (The annual accounts in Spain must be submitted to the company register before 30 June each year, but with COVID-19, the administrative deadlines have been extended until 30 September 2020 for the presentation of the accounts for 2019), while $46.3 \%$ of entrepreneurs in Spain cease their activity before the fourth year [59]. In business incubators, the survival rate reaches $90.8 \%$ by the fourth year, and those that are constituted as limited companies continue to operate at $100 \%$. Business incubators contribute to business sustainability to a greater extent than the companies that are set up outside the incubator [2].

The classification of companies between the most radical and the least radical innovation is established according to the results obtained by each entrepreneur in the five relevant items listed in Table 1, related to the introduction of new products/services in the market, their development, the frequency of their launch, the experimentation of new products, and the improvement of the quality 
of the existing ones. This table shows that the greatest difference lies in the strategy of introducing new products or services into the market, followed by experimentation with new products and the generation of new services. The average difference between both groups is 2.2 points; the maximum value reached by a company was 7 points, the minimum being 2.4 points.

Table 1. Average value of innovation items according to the type of company (The coincidence in the number of companies with a more radical versus less radical strategy responds to the result of the surveys, and in no case corresponds to a median).

\begin{tabular}{|c|c|c|c|c|c|c|c|}
\hline $\begin{array}{l}\text { Innovation } \\
\text { Type }\end{array}$ & No. & $\begin{array}{l}\text { 1.Introducing New } \\
\text { Products/Services }\end{array}$ & $\begin{array}{l}\text { 2.New Generation for Product } \\
\text { Development/Services }\end{array}$ & $\begin{array}{l}\text { 3.Release Frequency of } \\
\text { New Products/Services }\end{array}$ & $\begin{array}{l}\text { 4.Experiencing New } \\
\text { Products/Services }\end{array}$ & $\begin{array}{l}\text { 5.Improvement of Product } \\
\text { Quality/Existing Services }\end{array}$ & Average \\
\hline More Radical & 15 & 6.07 & 5.93 & 5.47 & 6.00 & 5.87 & 5.87 \\
\hline Less Radical & 15 & 3.13 & 3.67 & 3.53 & 3.67 & 4.64 & 3.67 \\
\hline Total & 30 & 4.60 & 4.80 & 4.50 & 4.83 & 5.28 & 4.77 \\
\hline Differ. & & 2.93 & 2.27 & 1.93 & 2.33 & 1.22 & 2.20 \\
\hline
\end{tabular}

Source: Own elaboration based on business surveys.

Table 2 shows that there is a predominance of entrepreneurs with university education level (83.3\%), a figure higher than that previously published, which represented 66.7\% [58]. The higher the level of training, the greater the chances of success and sustainability of the entrepreneurial initiative. The fact that the company was constituted as a limited company explains the higher level of training of the entrepreneur, since this type of company entails greater formal obligations, thus requiring the entrepreneur to have higher qualifications. There are no significant differences between the training of entrepreneurs in companies according to whether they have a more or less radical innovation strategy.

Among university entrepreneurs, those in science predominate (64.2\%). The hours of training received in business management amounted to 879 on average per entrepreneur, including the regulated training of those who had studied business administration or similar. In addition, it is observed that they have an average experience as an entrepreneur in their sector of 7.75 years, in other management sectors (6.5 years on average), or of 15.26 years as an employee. The experience of the entrepreneur is another factor that influences the sustainability of the business initiatives that are created in business incubators.

Table 2. Training of entrepreneurs according to the degree of innovation.

\begin{tabular}{ccc}
\hline Entrepreneurs Innovation & \% More Radical & \% Less Radical \\
\hline Secondary Education & $6.7 \%$ & $6.7 \%$ \\
Vocational Training & $13.3 \%$ & $6.7 \%$ \\
University Degree & $80.0 \%$ & $86.7 \%$ \\
Total & $\mathbf{1 0 0 . 0 \%}$ & $\mathbf{1 0 0 . 0} \%$ \\
\hline
\end{tabular}

Source: Own elaboration based on business surveys.

Table 3 shows how the companies subject to study are mainly dedicated to professional services, although this is more the case for radical companies (73.3\%) than for the less radical ones $(60 \%)$. The ratio is lower than those presented by another work, where it was $82.1 \%$ [58].

Table 3. Business activities according to the degree of innovation.

\begin{tabular}{ccc}
\hline Activity & \% More Radical & \% Less Radical \\
\hline Commerce & $6.7 \%$ & $26.7 \%$ \\
Industrial & $20.0 \%$ & $6.7 \%$ \\
Primary & & $6.7 \%$ \\
Professional services & $73.3 \%$ & $60.0 \%$ \\
Total & $\mathbf{1 0 0 . 0 \%}$ & $\mathbf{1 0 0 . 0} \%$ \\
\hline
\end{tabular}

Source: Own elaboration based on business surveys. 
An important indicator is the number of workers (including business promoters) per company, with an initial average of 2.63 people working full time, resulting in a $55.9 \%$ increase in jobs. Therefore, the average currently amounts to 4.1 people, which shows that these business initiatives encourage job creation and are sustainable over time due to their high business survival rates. According to a previous study, the impact of business incubators on job creation was analyzed in such a way that, in Galicia (Spain), 3498 jobs had been created through these companies [60].

When classifying the companies according to the type of innovative strategy, those with radical innovative strategies create 3.45 jobs on average, compared to 4.79 for those with non-radical strategies. A previous study on companies operating in incubators was carried out, distinguishing between technological and non-technological companies, where annual job creation per incubator and company was practically similar [61].

\subsection{Balance Sheet Analysis}

Table 4 shows the evolution of the balance sheet of the most radical companies in their innovation strategy for the period 2012-2018. The fact that they have been operating for 7 years shows that the survival rate of the companies that have been in the incubators is high. This is in line with another work where it was said that the mortality rate of the companies that emerged from the incubators was 9.2\% [55]. This rate is much lower than that of the companies that did not go through the incubators, which amounts to $46.3 \%$. In general terms, there are no major variations in the value of assets, although it decreases in the years 2013-2015 and increases later in 2018. Rather, there is an inverse evolution between current and non-current assets, in such a way that the latter are reduced, largely due to the fall in the asset value of tangible fixed assets, which is related to the depreciation of the assets and the difficulty of their replacement with the crisis (the expectation of sale decreases and the difficulty of financial disposal increases). On the other hand, current assets increased from 11,158 to 19,872 euros, due to a $159.3 \%$ increase in the inventory and a $51.7 \%$ increase in current assets.

An analysis of the situation of liabilities and equity reveals a $44.2 \%$ reduction in equity, which is largely due to the presence of a continued negative result until 2017, reaching a cumulative negative result of $-12,725$ euros in 2018, when the share capital is 18,503 euros. Non-current liabilities did not experience major fluctuations, although their evolution was growing $(\Delta 27.4 \% \mathrm{~m} / \mathrm{L}$ debt $)$ in recent years. On the other hand, current liabilities increased every year $(\Delta 72.6 \%$ in the period), reaching the highest value in 2018 with 23,844 euros of debt, highlighting the increase in debt from commercial creditors. This explains why the working capital is negative in all years, evidencing structural financial weakness, with great liquidity tensions and financial management dedicated to the immediacy of the operation.

Table 4. Balance sheet of more radical companies in innovation. Thousands of euros.

\begin{tabular}{cccccccc}
\hline Balance & $\mathbf{2 0 1 8}$ & $\mathbf{2 0 1 7}$ & $\mathbf{2 0 1 6}$ & $\mathbf{2 0 1 5}$ & $\mathbf{2 0 1 4}$ & $\mathbf{2 0 1 3}$ & $\mathbf{2 0 1 2}$ \\
\hline Non-current assets & 27,334 & 27,286 & 28,543 & 25,647 & 26,537 & 32,155 & 32.159 \\
Intangible assets & 681 & 1255 & 1251 & 912 & 498 & 645 & 853 \\
Tangible fixed assets & 23,044 & 21,994 & 20,897 & 20,039 & 20,538 & 25,351 & 28,476 \\
Investments in group companies & 245 & & 2010 & & & 2046 & 867 \\
Deferred tax assets & 3182 & 3499 & 3534 & 4017 & 3564 & 3256 & 809 \\
Current assets & 19,872 & 14,609 & 13,807 & 11,565 & 8783 & 6903 & 11,158 \\
Non-current assets for sale & & & 871 & 1453 & 1135 & & \\
Inventory & 9038 & 6700 & 5908 & 2938 & 2682 & 1725 & 3485 \\
Commercial debtors & 8458 & 5767 & 5038 & 3622 & 3888 & 3251 & 6352 \\
Investments in group companies & & 224 & 60 & 43 & 6 & & \\
Accruals & 55 & 45 & 35 & 25 & 5 & 2 & 324 \\
Cash & 2234 & 1545 & 1707 & 2780 & 571 & 1374 & 698 \\
Assets & 47,206 & 41,895 & 42,350 & 37,212 & 35,320 & 39,058 & 43,317 \\
Equity & 10,955 & 10,058 & 10,617 & 7411 & 7692 & 13,563 & 20,323 \\
Shareholders' equity & 9192 & 8147 & 8453 & 5060 & 5279 & 10,281 & 16,476 \\
Capital & 18,503 & 18,696 & 18,898 & 18,898 & 18,682 & 18,646 & 18,643 \\
\hline
\end{tabular}


Table 4. Cont.

\begin{tabular}{cccccccc}
\hline Balance & $\mathbf{2 0 1 8}$ & $\mathbf{2 0 1 7}$ & $\mathbf{2 0 1 6}$ & $\mathbf{2 0 1 5}$ & $\mathbf{2 0 1 4}$ & $\mathbf{2 0 1 3}$ & $\mathbf{2 0 1 2}$ \\
\hline Share premium & & 190 & 67 & 28 & & & \\
$\quad$ Reserves & 694 & 697 & 518 & 573 & 94 & 94 & 91 \\
Shares and holdings in own equity & & & -34 & -35 & -20 & & \\
Results from previous years & $-12,725$ & $-12,740$ & $-14,459$ & $-14,474$ & $-11,399$ & -4052 & -603 \\
Other shareholder contributions & 1500 & 1500 & 1500 & & & & \\
$\quad$ Financial result & 1220 & -196 & 1963 & 69 & -2077 & -4407 & -1656 \\
$\quad$ Subsidies & 1764 & 1912 & 2164 & 2352 & 2413 & 3282 & 3848 \\
Non-current liabilities & 12,407 & 13,677 & 14,033 & 17,100 & 14,247 & 15,462 & 9181 \\
$\quad$ Supplies & 265 & & & & & & 56 \\
$\quad$ Debt & 9522 & 10,041 & 10,339 & 10,269 & 13,213 & 14,055 & 7476 \\
Liabilities to group companies & 2000 & 3000 & 3000 & 6060 & & & \\
Deferred tax liabilities & 620 & 635 & 694 & 772 & 1034 & 1407 & 1649 \\
$\quad$ Current liabilities & 23,844 & 18,160 & 17,700 & 12,701 & 13,381 & 10,033 & 13,814 \\
Liabilities held for sale & & & 817 & 830 & 2204 & & \\
$\quad$ Short-term debt & 5229 & 5223 & 4404 & 4520 & 4731 & 4218 & 9224 \\
Liabilities to group companies & 1200 & 88 & 237 & 109 & & 197 &. \\
Commercial creditors & 17,416 & 12,849 & 12,243 & 7242 & 6445 & 5618 & 4589 \\
Equity and liabilities & 47,206 & 41,895 & 42,350 & 37,212 & 35,320 & 39,058 & 43,318 \\
\hline Source: Own elaboration based on data obtained from SABI (Database on companies in Spain and Portugal).
\end{tabular}

Table 5 shows that the balance sheet of the less radical companies is an asset value ten times lower than that of the more radical ones. In turn, non-current assets increased to more than double over the years, as a result of the increase in tangible fixed assets, quadrupling. Current assets have remained constant in recent years, which was not the case for the most radical companies. In terms of equity, it can be seen that the equity of less radical companies increases exponentially over the years, and that reserves grow every year. Current liabilities in less radical companies are lower and have grown slightly in the last year. Another differential fact is that in less radical companies the working capital is positive, except for the 2012 balance sheet, which denotes less investment and business diversification.

Table 5. Balance sheet of less radical companies in innovation. Thousands of euros.

\begin{tabular}{|c|c|c|c|c|c|c|c|}
\hline Balance & 2018 & 2017 & 2016 & 2015 & 2014 & 2013 & 2012 \\
\hline \multicolumn{8}{|l|}{ Assets } \\
\hline Non-current assets & 508 & 494 & 529 & 332 & 264 & 220 & 233 \\
\hline Intangible assets & 3 & 7 & 5 & 5 & 2 & 1 & 1 \\
\hline Tangible fixed assets & 314 & 270 & 198 & 215 & 226 & 82 & 75 \\
\hline Investments in group companies & 162 & 162 & 225 & 64 & & & \\
\hline Financial investments & 26 & 28 & 86 & 45 & 34 & 118 & 133 \\
\hline Deferred tax assets & 3 & 27 & 14 & 3 & 1 & 19 & 24 \\
\hline Current assets & 3928 & 3961 & 2314 & 2235 & 1515 & 617 & 780 \\
\hline Inventory & 841 & 981 & 307 & 350 & 213 & 162 & 157 \\
\hline Commercial debtors & 2372 & 2131 & 1364 & 1131 & 720 & 340 & 519 \\
\hline Investments in group companies & 25 & 25 & 3 & & & & \\
\hline Accruals & 59 & 91 & 1 & 1 & 1 & 1 & 1 \\
\hline Cash & 550 & 710 & 553 & 735 & 564 & 111 & 100 \\
\hline Assets & 4437 & 4455 & 2842 & 2567 & 1779 & 838 & 1013 \\
\hline Equity & 905 & 791 & 655 & 764 & 474 & 57 & 5 \\
\hline Shareholders' equity & 905 & 791 & 654 & 764 & 474 & 57 & 5 \\
\hline Capital & 203 & 256 & 206 & 219 & 193 & 82 & 82 \\
\hline Reserves & 469 & 265 & 245 & 115 & 79 & 42 & 29 \\
\hline Results from previous years & 118 & 102 & 19 & -88 & -252 & -109 & -99 \\
\hline Other shareholder contributions & & & 1 & 297 & 297 & & \\
\hline Financial result & 114 & 168 & 185 & 221 & 156 & 41 & -7 \\
\hline Non-current liabilities & 255 & 499 & 444 & 257 & 260 & 212 & 135 \\
\hline Debt & 255 & 499 & 443 & 256 & 260 & 212 & 135 \\
\hline Current liabilities & 3277 & 3164 & 1743 & 1545 & 1044 & 569 & 873 \\
\hline Supplies & & & & 177 & 177 & & \\
\hline Debt & 837 & 589 & 249 & 161 & 161 & 121 & 291 \\
\hline Commercial creditors & 2441 & 2563 & 1482 & 1197 & 694 & 436 & 569 \\
\hline Accruals & & 13 & 12 & 11 & 12 & 12 & 13 \\
\hline Equity and liabilities & 4437 & 4455 & 2842 & 2567 & 1779 & 838 & 1013 \\
\hline
\end{tabular}

Source: Own elaboration based on data obtained from SABI. 
Table 6 briefly shows the comparative data between both types of companies, where the greatest difference is the size of their balance sheets. The companies with more radical innovation have larger balance sheets with a very high weight of non-current assets (69.7\%) compared to only $14.4 \%$ of the less radical companies. Liabilities exceed $70 \%$ in both types of companies, although there is a greater imbalance in the more radical companies. This stems from the fact that they have few non-current liabilities and assets in relation to the weight of their non-current assets, generating a risk that translates into negative working capital, while the less radical companies have positive working capital despite having current liabilities of $68.1 \%$, but which are lower than current assets $(85.6 \%)$.

Table 6. Comparison of balance sheets between more and less radical companies in innovation. Average values 2012-2018.

\begin{tabular}{ccccc}
\hline \multirow{2}{*}{ Assets } & \multicolumn{2}{c}{ More Radical Companies } & \multicolumn{2}{c}{ Less Radical Companies } \\
\cline { 2 - 5 } & Thousands $\mathbf{€}$ & $\mathbf{\%}$ & Thousands $\mathbf{€}$ & $\mathbf{\%}$ \\
\hline Non-current assets & $28,523.0$ & $69.7 \%$ & 368.6 & $14.4 \%$ \\
Current assets & $12,385.3$ & $30.3 \%$ & 2192.9 & $85.6 \%$ \\
Total Assets & $40,908.3$ & $100.0 \%$ & 2561.6 & $100.0 \%$ \\
Liabilities & & & & \\
$\quad$ Equity & $11,517.0$ & $28.2 \%$ & 521.6 & $20.4 \%$ \\
Non-current liabilities & $13,729.6$ & $33.6 \%$ & 294.6 & $11.5 \%$ \\
Current liabilities & $15,661.9$ & $38.3 \%$ & 1745.0 & $68.1 \%$ \\
Total equity and liabilities & $40,908.4$ & $100.0 \%$ & 2561.6 & $100.0 \%$ \\
Working Capital & -3276.6 & & 348.3 & \\
\hline
\end{tabular}

Source: Own elaboration based on data obtained from SABI.

\subsection{Analysis of the Income Statement}

Table 7 shows the income statement of companies with a more radical innovation strategy. Since 2012-2018 there has been a 40.6\% increase in sales, which shows a growing presence in the market. However, supplies grew by $118 \%$, representing more than $\frac{3}{4}$ parts of the number of sales $(76.2 \%)$, compared to $15 \%$ of staff costs. This is indicative of a greater weight of commercial companies in the configuration of the global account, and also increases with the same intensity as sales. In absolute terms, depreciation remained the same, but as the level of activity increased, they represent a proportionally lower value. Another positive aspect is the change in the trend of the operating result from negative in the first years to positive in the last few years, and increasingly so, representing $4.1 \%$ of the level of sales when in the first years it was $-4.1 \%$. The behavior of the financial result is irregular. All this translates into a positive pre-tax result of $3.1 \%$ for 2018 , when in 2012 it was negative by $-4.4 \%$.

Table 7. Income statement of more radical innovation companies. Thousands of euros.

\begin{tabular}{|c|c|c|c|c|c|c|c|c|c|c|c|c|c|c|}
\hline \multirow[b]{2}{*}{ Revenues } & \multicolumn{2}{|c|}{2018} & \multicolumn{2}{|c|}{2017} & \multicolumn{2}{|c|}{2016} & \multicolumn{2}{|c|}{2015} & \multicolumn{2}{|c|}{2014} & \multicolumn{2}{|c|}{2013} & \multicolumn{2}{|c|}{2012} \\
\hline & 53,474 & $100 \%$ & 49,179 & $100 \%$ & 35,886 & $100 \%$ & 31,285 & $100 \%$ & 28,443 & $100 \%$ & 17,845 & $100 \%$ & 38,020 & $100 \%$ \\
\hline Inventory change & 2524 & $4.7 \%$ & 1309 & $2.7 \%$ & 1159 & $3.2 \%$ & 79 & $0.3 \%$ & 586 & $2.1 \%$ & -431 & $-2.4 \%$ & -2412 & $-6.3 \%$ \\
\hline Tasks performed by the company for assets & 643 & $1.2 \%$ & 1704 & $3.5 \%$ & 671 & $1.9 \%$ & 673 & $2.2 \%$ & 492 & $1.7 \%$ & 337 & $1.9 \%$ & 281 & $0.7 \%$ \\
\hline Supplies & $-40,739$ & $-76.2 \%$ & $-39,013$ & $-79.3 \%$ & $-24,777$ & $-69.0 \%$ & $-19,603$ & $-62.7 \%$ & $-18,915$ & $-66.5 \%$ & $-12,996$ & $-72.8 \%$ & $-25,654$ & $-67.5 \%$ \\
\hline Other operating revenue & 287 & $0.5 \%$ & 60 & $0.1 \%$ & 241 & $0.7 \%$ & 259 & $0.8 \%$ & 367 & $1.3 \%$ & 70 & $0.4 \%$ & 134 & $0.4 \%$ \\
\hline Personnel expenses & -7950 & $-14.9 \%$ & -7391 & $-15.0 \%$ & -6594 & $-18.4 \%$ & -7916 & $-25.3 \%$ & -7076 & $-24.9 \%$ & -5515 & $-30.9 \%$ & -5748 & $-15.1 \%$ \\
\hline Other operating expenses & -4207 & $-7.9 \%$ & -4577 & $-9.3 \%$ & -3376 & $-9.4 \%$ & -3436 & $-11.0 \%$ & -3128 & $-11.0 \%$ & -3076 & $-17.2 \%$ & -3687 & $-9.7 \%$ \\
\hline Depreciation of fixed assets & -2042 & $-3.8 \%$ & -1890 & $-3.8 \%$ & -1930 & $-5.4 \%$ & -1678 & $-5.4 \%$ & -2205 & $-7.8 \%$ & -2806 & $-15.7 \%$ & -3129 & $-8.2 \%$ \\
\hline Subsidies & 202 & $0.4 \%$ & 236 & $0.5 \%$ & 361 & $1.0 \%$ & 365 & $1.2 \%$ & 402 & $1.4 \%$ & 644 & $3.6 \%$ & 652 & $1.7 \%$ \\
\hline Disposal of fixed assets & 4 & $0.0 \%$ & 497 & $1.0 \%$ & 847 & $2.4 \%$ & 1318 & $4.2 \%$ & 6 & $0.0 \%$ & 42 & $0.2 \%$ & 2 & $0.0 \%$ \\
\hline Other results & 22 & $0.0 \%$ & 125 & $0.3 \%$ & -93 & $-0.3 \%$ & -12 & $0.0 \%$ & -3 & $0.0 \%$ & -29 & $-0.2 \%$ & -5 & $0.0 \%$ \\
\hline Operating result & 2218 & $4.1 \%$ & 238 & $0.5 \%$ & 2396 & $6.7 \%$ & 1333 & $4.3 \%$ & -1032 & $-3.6 \%$ & -5916 & $-33.2 \%$ & -1546 & $-4.1 \%$ \\
\hline Financial result & -563 & $-1.1 \%$ & -427 & $-0.9 \%$ & 28 & $0.1 \%$ & 2263 & $7.2 \%$ & -1279 & $-4.5 \%$ & -934 & $-5.2 \%$ & -835 & $-2.2 \%$ \\
\hline Pre-tax result & 1656 & $3.1 \%$ & -189 & $-0.4 \%$ & 2424 & $6.8 \%$ & -930 & $-3.0 \%$ & -2311 & $-8.1 \%$ & -6850 & $-38.4 \%$ & -2382 & $-6.3 \%$ \\
\hline Income taxes & -436 & $-0.8 \%$ & -7 & $0.0 \%$ & -460 & $-1.3 \%$ & 999 & $3.2 \%$ & 234 & $0.8 \%$ & 2444 & $13.7 \%$ & 725 & $1.9 \%$ \\
\hline Financial result & 1220 & $2.3 \%$ & -196 & $-0.4 \%$ & 1963 & $5.5 \%$ & 69 & $0.2 \%$ & -2077 & $-7.3 \%$ & -4407 & $-24.7 \%$ & -1656 & $-4.4 \%$ \\
\hline
\end{tabular}

Source: Own elaboration based on data obtained from SABI.

Table 8 presents the income statement of less radical innovation companies. The level of sales increased in the period $2012-2018$ by $549 \%$, which is much higher than the increase in sales of radical innovation companies, although the volume of sales for 2018 is $557.3 \%$ compared to the less radical 
companies. In the less radical companies, it can be seen that the volume of supply expenses is $81.3 \%$ in 2018, a volume very similar to that of the most radical companies, $76.2 \%$ in the same year. This again shows the maximum presence of commercial companies. Personnel expenses are only $5.1 \%$ of total income, a very low ratio compared to more radical companies (14.9\%).

The pre-tax result is higher in the non-radicals, always obtaining a profit, except in 2012. One of the justifications for the business incubators is the contribution that the companies that leave the incubator make to society through the payment of taxes, among other socioeconomic benefits [62]. Through the "Integral Model of economic profitability," it was demonstrated that what was recovered by the public administrations was greater than the investment made in the business incubators, which generate wealth-creating companies. As for our sequence, less radical companies contribute to the tax payment every year of the period (2012-2018), with the exception of the first one, while the radical ones do not, as they give losses.

Table 8. Income statement of less radical innovation companies. Thousands of euros.

\begin{tabular}{|c|c|c|c|c|c|c|c|c|c|c|c|c|c|c|}
\hline \multirow[b]{2}{*}{ Revenues } & \multicolumn{2}{|c|}{2018} & \multicolumn{2}{|c|}{2017} & \multicolumn{2}{|c|}{2016} & \multicolumn{2}{|c|}{2015} & \multicolumn{2}{|c|}{2014} & \multicolumn{2}{|c|}{2013} & \multicolumn{2}{|c|}{2012} \\
\hline & 9594 & $100 \%$ & 12,738 & $100 \%$ & 10,388 & $100 \%$ & 9005 & $100 \%$ & 4968 & $100 \%$ & 1304 & $100 \%$ & 1478 & $100 \%$ \\
\hline Inventory change & -4 & $0.0 \%$ & 7 & $0.1 \%$ & & $0.0 \%$ & 49 & $0.5 \%$ & 5 & $0.1 \%$ & 49 & $3.8 \%$ & 45 & $3.0 \%$ \\
\hline Supplies & -7798 & $-81.3 \%$ & -9619 & $-75.5 \%$ & -7803 & $-75.1 \%$ & -7154 & $-79.4 \%$ & -3495 & $-70.4 \%$ & -688 & $-52.8 \%$ & -770 & $-52.1 \%$ \\
\hline Other operating revenue & 313 & $3.3 \%$ & 16 & $0.1 \%$ & 7 & $0.1 \%$ & 10 & $0.1 \%$ & 17 & $0.3 \%$ & 3 & $0.2 \%$ & 10 & $0.7 \%$ \\
\hline Personnel expenses & -494 & $-5.1 \%$ & -820 & $-6.4 \%$ & -831 & $-8.0 \%$ & -652 & $-7.2 \%$ & -619 & $-12.5 \%$ & -372 & $-28.5 \%$ & -545 & $-36.9 \%$ \\
\hline Other operating expenses & -1545 & $-16.1 \%$ & -2021 & $-15.9 \%$ & -1442 & $-13.9 \%$ & -907 & $-10.1 \%$ & -630 & $-12.7 \%$ & -201 & $-15.4 \%$ & -200 & $-13.5 \%$ \\
\hline Depreciation of fixed assets & -48 & $-0.5 \%$ & -51 & $-0.4 \%$ & -43 & $-0.4 \%$ & -39 & $-0.4 \%$ & -40 & $-0.8 \%$ & -22 & $-1.7 \%$ & -11 & $-0.7 \%$ \\
\hline Disposal of fixed assets & & & 3 & $0.0 \%$ & -3 & $0.0 \%$ & -2 & $0.0 \%$ & & $0.0 \%$ & -1 & $-0.1 \%$ & & $0.0 \%$ \\
\hline Other results & 225 & $2.3 \%$ & 9 & $0.1 \%$ & 8 & $0.1 \%$ & -1 & $0.0 \%$ & 16 & $0.3 \%$ & -3 & $-0.2 \%$ & & $0.0 \%$ \\
\hline Operating result & 245 & $2.6 \%$ & 261 & $2.0 \%$ & 282 & $2.7 \%$ & 310 & $3.4 \%$ & 222 & $4.5 \%$ & 68 & $5.2 \%$ & 5 & $0.3 \%$ \\
\hline Financial result & -87 & $-0.9 \%$ & -41 & $-0.3 \%$ & -10 & $-0.1 \%$ & -35 & $-0.4 \%$ & -29 & $-0.6 \%$ & -15 & $-1.2 \%$ & -10 & $-0.7 \%$ \\
\hline Pre-tax result & 159 & $1.7 \%$ & 220 & $1.7 \%$ & 272 & $2.6 \%$ & 276 & $3.1 \%$ & 193 & $3.9 \%$ & 53 & $4.1 \%$ & -5 & $-0.3 \%$ \\
\hline Income taxes & -44 & $-0.5 \%$ & -52 & $-0.4 \%$ & -87 & $-0.8 \%$ & -54 & $-0.6 \%$ & -37 & $-0.7 \%$ & -12 & $-0.9 \%$ & -2 & $-0.1 \%$ \\
\hline Financial result & 114 & $1.2 \%$ & 168 & $1.3 \%$ & 185 & $1.8 \%$ & 221 & $2.5 \%$ & 156 & $3.1 \%$ & 41 & $3.1 \%$ & -7 & $-0.5 \%$ \\
\hline
\end{tabular}

Source: Own elaboration based on data obtained from SABI.

By analyzing the main ratios of the income statement and comparing the average data for the period 2012-2018 between companies more and less radical in terms of innovation (Table 9), the following results can be extracted: a higher volume of sales in the former; a very similar percentage in terms of supplies, which are very high in both cases, reflecting the commercial nature of the companies analyzed; a significant difference in terms of personnel expenses, which is $19 \%$ in the more radical companies and falls to $8.8 \%$ in the less radical ones; a higher percentage of financial expenses in the more radical companies ( $3.4 \%$ of income); the less radical companies are those who contribute most to the state by paying more corporation tax (the most innovative, given their losses, do not contribute).

Table 9. Comparison of balance sheets between more and less radical companies in innovation. Average values 2012-2018.

\begin{tabular}{ccccc}
\hline & \multicolumn{2}{c}{ More Radical } & \multicolumn{2}{c}{ Less Radical } \\
\cline { 2 - 5 } & $\boldsymbol{\epsilon}$ & $\mathbf{\%}$ & $\boldsymbol{\epsilon}$ & $\%$ \\
\hline Revenues & $36,304.57$ & $100 \%$ & 7067.86 & $100 \%$ \\
Inventory change & 402.00 & $1.1 \%$ & 21.57 & $0.3 \%$ \\
Supplies & $-25,956.71$ & $-71.5 \%$ & -5332.43 & $-75.4 \%$ \\
Other operating revenue & 203 & $0.6 \%$ & 53.71 & $0.8 \%$ \\
Personnel expenses & -6884.29 & $-19.0 \%$ & -619.00 & $-8.8 \%$ \\
Other expenditures & -3641.00 & $-10.0 \%$ & -992.29 & $-14.0 \%$ \\
Amortization & -2240.00 & $-6.2 \%$ & -36.29 & $-0.5 \%$ \\
Other results & 0.71 & $0.0 \%$ & 36.29 & $0.5 \%$ \\
Operating result & -329.86 & $-0.9 \%$ & 199.00 & $2.8 \%$ \\
Financial result & -896.14 & $-2.5 \%$ & -32.43 & $0 \%$ \\
Pre-tax result & -1226.00 & $-3.4 \%$ & 166.86 & $2 \%$ \\
Taxes on profits & 499.86 & $1.4 \%$ & -41.14 & $-1 \%$ \\
Financial result & -726.29 & $-2.0 \%$ & 125.43 & $2 \%$ \\
\hline
\end{tabular}




\subsection{Economic and Financial Ratios}

Table 10 contains the main ratios of both more and less radical companies in their innovation strategy. Regarding the profitability ratios of the former, although in the last year it was positive, it has been dragging on a negative evolution since 2012, which gives it negative ratios. Less radical companies present ratios that may be considered good (except in 2012, they have always been positive even though they vary from one year to another).

In the operations section, it should be noted that the inventory ratio of the more radical companies has worsened, rotating less over time, and thus reducing it by almost half. The average collection period is maintained, while the average payment period increases, which implicitly means greater financing from suppliers and creditors. Less radical companies can be considered to have good asset and inventory turnover ratios, which in recent years have rotated once a month. On the other hand, the collection period is longer than the payment period, which is usually the case.

When focusing on the structure ratios in the most radical companies, it can be seen that the solvency ratio is below what is recommended, since it should be over 1.5 , and in no year does it reach one unit. These companies present bad ratios in general and worse than the less radical ones whose solvency ratio, although below what is considered standard, is closer to 1.5.

Analyzing the last section of ratios per employee, it is indicated that the profits per professional in the case of the most radical companies are negative, with low operating income per employee, higher average cost of the same and worse working capital ratios than in the less radical companies in innovation.

Table 10. Comparative analysis, financial ratios of more versus less radical companies.

\begin{tabular}{ccc}
\hline Financial Ratios & More Radical & Less Radical \\
\hline Profitability/own resources (\%) & -9.82 & 30.88 \\
Profitability/capital employed (\%) & -0.63 & 22.94 \\
Profitability/total assets (\%) & -3.33 & 6.50 \\
Profit margin (\%) & -6.57 & 2.41 \\
Operations & & \\
Net asset turnover & 1.48 & 8.43 \\
Interest hedging ratio & -0.21 & 5.34 \\
Inventory turnover & 8.77 & 12.21 \\
Collection period (days) & 52 & 73 \\
Credit period (days) & 73 & 53 \\
Structure & & \\
Solvency ratio & 0.78 & 1.24 \\
Liquidity ratio & 0.51 & 1.00 \\
Financial autonomy ratios & 0.92 & 1.15 \\
Solvency coefficient (\%) & 27.95 & 17.85 \\
Leverage (\%) & 172.11 & 676.05 \\
Per employee & & \\
Benefit/employee & -8 & 5 \\
Operating income/employee & 174 & 209 \\
Labor costs/operating revenue (\%) & 20.54 & 18.09 \\
Average cost/employees & 34 & 29 \\
Own resources/employee & 65 & 19 \\
Working capital/employee & 15 & 35 \\
Total assets/employee & 208 & 103 \\
\hline Soure Own & &
\end{tabular}

Source: Own elaboration based on data obtained from SABI.

Appendices A and B contain a comparison of the latest company accounts presented in the commercial register, their main ratios and determines whether there are significant differences between more radical companies in terms of innovation strategy and the less radical ones. For this purpose, the Levene's test was applied to carry out a comparison of averages between both groups. No significant differences were observed in any ratio of the balance sheet, the income statement, 
or in the economic ratios since the bilateral sig is always clearly less than 0.05 . This indicates that, although differences can be found in the measures due to the size of some of the companies, it cannot be concluded that this derives from belonging to the group of companies with more radical or less radical commercial strategies.

\section{Conclusions}

Business incubators are unquestionable instruments for the creation of companies with many years of experience and major international presence. In Europe, and specifically in Spain, they are largely financed by public funds, as their profitability is economic and social. Their main outputs are the creation of companies with high survival rates, which make them sustainable over time, generating stable employment, and constantly contributing to the collection of public revenue, in addition to other economic and social benefits that stimulate growth and development.

Business incubators have evolved away from a mere cession of space to the entrepreneur and providing services linked to training, management, innovation, for a limited time, as they are public aid programs.

The main objectives of this study focus on whether innovation in companies located in incubators has a positive influence on business growth [1] and whether the training of entrepreneurs with the help of incubators contributes to creating companies with high survival rates [2].

Among the corporate companies that have answered the questionnaires, half can be classified as radical companies in their innovation strategy with an average of 5.87 in all their items and the other half as not very radical, with an average value of 3.67. These companies are job generators, with an average of 4.1 people per company. The creation of qualified employment in companies that are sustained over time is one of the facts that contribute to the economic and social profitability of business incubators. There are differences in the balance sheets of companies with more radical innovation strategies as opposed to less radical ones. The former are larger, have less working capital, and are more likely to face short-term obligations. On the other hand, the higher turnover of the more radical companies does not translate into positive income statements, nor have they grown more in sales for the period 2012-2018. In contrast, the less radical ones sell less, grow more, and present a positive result for that period; nor are the main ratios of profitability, asset turnover, inventory, solvency, liquidity or profitability per employee better in companies with stronger innovative strategies. However, even though in general better ratios are found in the latter companies than in the former, the comparison of averages with independent samples applying the Levene's test does not show that the differences are significant due to the intensity of the innovation strategy. Therefore, the results obtained do not confirm, but neither do they contradict, the link of innovation with company growth and higher profitability [1]. This could be explained by the fact that there is a lot of innovation in entrepreneurs located in business incubators [27], and therefore there are no differences according to the degree of innovation.

Entrepreneurs in business incubators generate an average of 4.1 jobs per company. In addition, the survival rate of the companies that answered the questionnaire in the seventh year was $100 \%$, while $46.3 \%$ of entrepreneurs in Spain ceased their activity before the fourth year. Therefore, we conclude that qualified employment is created in companies that are sustained over time, which is one of the facts that contribute to economic growth and social welfare [2,6,8,24].

This study concludes that, from the selected sample, $83.3 \%$ of the entrepreneurs established in business incubators in Spain have university training and 64.2\% lean toward the branches of science, which favors the survival of businesses and the creation of qualified employment. All this favors the sustainability of the productive and business model which, being more intensive in knowledge and $R \& D$, becomes more competitive in the market. Therefore, taking into account the importance of knowledge for economic growth [6] and the fact that the entrepreneur is the main person responsible for business success [25], the importance of entrepreneurial training becomes evident, which has a positive effect on the survival of companies. 
As a final conclusion, it can be said that business incubators generate profitable companies that are sustainable over time, having entrepreneurs with extensive experience in management and high qualifications. This generates quality and lasting employment [2]. However, there is no evidence of significant differences between the more or less innovative nature of companies.

The limitations found in this article have been the sample size, since only thirty companies had presented their annual accounts in the Commercial Register and had answered the questionnaire that allowed for the classification according to their degree of innovation. Considering that the value of the research lies in the importance of studies on the relationship between innovation, training, and wealth-generating sustainability in business incubators in the current knowledge economy, it would be appropriate to study whether the conclusions of this study are fulfilled in other countries and to carry out comparative analyses in order to check their applicability in a general context.

Finally, in line with the idea that STI may be a key way to achieve the SDGs [41], a possible future line of research could focus on how the inclusion of SDGs interferes with the survival and sustainability of companies as well as their profitability and whether there is added value in including SDGs.

Author Contributions: Conceptualization, F.J.F.-S. and V.M.-R.; methodology, F.J.F.-S. and M.O.D.C.V.; formal analysis, F.J.F.-S. and M.O.D.C.V.; investigation, F.J.F.-S. and V.M.-R.; writing-original draft preparation, F.J.F.-S.; writing-review and editing, V.M.-R.; funding acquisition, F.J.F.-S. All authors have read and agreed to the published version of the manuscript.

Funding: This research was funded by FUNCAS, grant number EF001-2018.

Conflicts of Interest: The authors declare no conflict of interest.

\section{Appendix A}

Table A1. Comparison of independent sample averages (companies with more radical and less radical strategies) of different management ratios applying the Levene's test, year 2018.

\begin{tabular}{|c|c|c|c|c|c|}
\hline Concept & Company & $\mathbf{N}$ & Mean & Standard Deviation & Standard Error of the Mean \\
\hline \multirow{2}{*}{ Fixed assets } & Less radical & 15 & $42,090.87$ & $87,936.33$ & $22,705.06$ \\
\hline & More radical & 15 & $1,910,535.00$ & $7,009,391.94$ & $1,809,817.22$ \\
\hline \multirow{2}{*}{ Current assets } & Less radical & 15 & $312,596.47$ & $662,145.46$ & $170,965.22$ \\
\hline & More radical & 15 & $1,387,898.27$ & $5,103,428.16$ & $1,317,699.49$ \\
\hline \multirow{2}{*}{ Total Assets } & Less radical & 15 & $354,687.40$ & $677,771.96$ & $174,999.97$ \\
\hline & More radical & 15 & $3,298,433.00$ & $12,112,310.54$ & $3,127,385.13$ \\
\hline \multirow{2}{*}{ Shareholders' equity } & Less radical & 15 & $75,555.00$ & $111,467.34$ & $28,780.74$ \\
\hline & More radical & 15 & $770,403.33$ & $2,814,979.14$ & $726,824.49$ \\
\hline \multirow{2}{*}{ Fixed liabilities } & Less radical & 7 & $54,210.71$ & $82,824.55$ & $31,304.74$ \\
\hline & More radical & 10 & $1,340,485.70$ & $3,871,580.16$ & $1,224,301.14$ \\
\hline \multirow{2}{*}{ Liquid liabilities } & Less radical & 15 & $253,834.27$ & $649,407.14$ & $167,676.20$ \\
\hline & More radical & 15 & $1,634,372.73$ & $6,127,857.92$ & $1,582,206.11$ \\
\hline \multirow{2}{*}{ Revenues } & Less radical & 15 & $727,214.27$ & $1,406,598.00$ & $363,182.04$ \\
\hline & More radical & 14 & $3,902,728.07$ & $14,340,546.99$ & $3,832,672.40$ \\
\hline \multirow{2}{*}{ Results } & Less radical & 15 & 5252.93 & $31,264.18$ & 8072.38 \\
\hline & More radical & 15 & $79,756.07$ & $315,758.66$ & $81,528.53$ \\
\hline \multirow{2}{*}{ Cash Flow } & Less radical & 15 & $9,533.60$ & $35,069.38$ & 9054.88 \\
\hline & More radical & 15 & $228,314.13$ & $837,275.79$ & $216,183.68$ \\
\hline \multirow{2}{*}{ Return on equity } & Less radical & 15 & -74.13 & 632.68 & 163.36 \\
\hline & More radical & 15 & 11.85 & 88.27 & 22.79 \\
\hline \multirow{2}{*}{ Net asset turnover } & Less radical & 15 & 52.01 & 165.95 & 42.85 \\
\hline & More radical & 15 & 0.38 & 4.25 & 1.10 \\
\hline \multirow{2}{*}{ Solvency ratio } & Less radical & 15 & 1.58 & 0.83 & 0.21 \\
\hline & More radical & 15 & 1.76 & 1.80 & 0.47 \\
\hline \multirow{2}{*}{ Benefit employee } & Less radical & 12 & 2.17 & 21.85 & 6.31 \\
\hline & More radical & 10 & 0.40 & 12.68 & 4.01 \\
\hline
\end{tabular}




\section{Appendix B}

Table A2. Comparison of independent sample averages (companies with more radical and less radical strategies) of different management ratios applying the Levene's test, year 2018.

\begin{tabular}{|c|c|c|c|c|c|}
\hline & & \multicolumn{2}{|c|}{ Levene's Test of Equality of Variance } & \multicolumn{2}{|c|}{$t$-Test for Equality of Means } \\
\hline & & $\mathbf{F}$ & Sig. & Sig. (bilateral) & Difference in Means \\
\hline \multirow{2}{*}{ Fixed assets } & Equal variances assumed & 4.507 & 0.043 & 0.311 & $-1,868,444.1333$ \\
\hline & Equal variances not assumed & & & 0.319 & $-1,868,444.1333$ \\
\hline \multirow{2}{*}{ Current_assets } & Equal variances assumed & 3.419 & 0.075 & 0.425 & $-1,075,301.8000$ \\
\hline & Equal variances not assumed & & & 0.431 & $-1,075,301.8000$ \\
\hline \multirow{2}{*}{ Total_assets } & Equal variances assumed & 4.055 & 0.054 & 0.355 & $-2,943,745.6000$ \\
\hline & Equal variances not assumed & & & 0.363 & $-2,943,745.6000$ \\
\hline \multirow{2}{*}{ Shareholders'_equity } & Equal variances assumed & 4.025 & 0.055 & 0.348 & $-694,848.3333$ \\
\hline & Equal variances not assumed & & & 0.356 & $-694,848.3333$ \\
\hline \multirow{2}{*}{ Fixed_liabilities } & Equal variances assumed & 3.301 & 0.089 & 0.398 & $-1,286,274.9857$ \\
\hline & Equal variances not assumed & & & 0.321 & $-1,286,274.9857$ \\
\hline \multirow{2}{*}{ Liquid_liabilities } & Equal variances assumed & 3.669 & 0.066 & 0.393 & $-1,380,538.4667$ \\
\hline & Equal variances not assumed & & & 0.400 & $-1,380,538.4667$ \\
\hline \multirow{2}{*}{ Revenues } & Equal variances assumed & 3.905 & 0.058 & 0.400 & $-3,175,513.8048$ \\
\hline & Equal variances not assumed & & & 0.424 & $-3,175,513.8048$ \\
\hline \multirow{2}{*}{ Results } & Equal variances assumed & 3.340 & 0.078 & 0.371 & $-74,503.1333$ \\
\hline & Equal variances not assumed & & & 0.378 & $-74,503.1333$ \\
\hline \multirow{2}{*}{ Cash_Flow } & Equal variances assumed & 4.066 & 0.053 & 0.321 & $-218,780.5333$ \\
\hline & Equal variances not assumed & & & 0.329 & $-218,780.5333$ \\
\hline \multirow{2}{*}{ Return_on_equity } & Equal variances assumed & 2.911 & 0.099 & 0.606 & -85.9800 \\
\hline & Equal variances not assumed & & & 0.610 & -85.9800 \\
\hline \multirow{2}{*}{ Net_asset_turnover } & Equal variances assumed & 4.314 & 0.047 & 0.238 & 51.6300 \\
\hline & Equal variances not assumed & & & 0.248 & 51.6300 \\
\hline \multirow{2}{*}{ Solvency_ratio } & Equal variances assumed & 4.756 & 0.038 & 0.724 & -0.1827 \\
\hline & Equal variances not assumed & & & 0.725 & -0.1827 \\
\hline \multirow{2}{*}{ Benefit_employee } & Equal variances assumed & 1.650 & 0.214 & 0.824 & 1.7667 \\
\hline & Equal variances not assumed & & & 0.816 & 1.7667 \\
\hline
\end{tabular}

Source: own elaboration.

\section{References}

1. Corsi, C.; Prencipe, A.; Capriotti, A. Linking organizational innovation, firm growth and firm size. J. Iberoam. Acad. Manag. 2019, 17, 24-49. [CrossRef]

2. Ferreiro-Seoane, F.J.; Rodríguez-Rodríguez, G.; Vaquero-García, A. Public Investment in Business incubators, is it better than doing nothing? Int. J. Entrep. Small Bus. 2018, 33, 553-574. [CrossRef]

3. Aerts, K.; Matthyssens, P.; Vandenbempt, K. Critical role and screening practices of European business incubators. Technovation 2007, 27, 254-267. [CrossRef]

4. Rice, M. Co-production of business assistance in business incubators. An explanatory study. J. Bus. Ventur. 2002, 17, 163-187. [CrossRef]

5. Cerdán-Chiscano, M.; Jiménez-Zarco, A.I.; Torrent-Sellens, J. Valorando los programas de apoyo al emprendedor en las incubadoras de empresas en Cataluña. Rev. Venez. Gerenc. 2013, 18, 408-433. [CrossRef]

6. Cai, L.; Naveed, A.; Sikandar, A.; Asadullah, K.; Shumaila, N. Role of Business Incubators as a Tool for Entrepreneurship Development: The Mediating and Moderating Role of Business Start-Up and Government Regulations. Sustainability 2020, 12, 1-23. [CrossRef]

7. Hausberg, J.P.; Korreck, S. Business incubators and accelerators: A co-citation analysis-based systematic literature review. J. Technol. Transf. 2020, 45, 151-176. [CrossRef]

8. Olkiewicz, M.; Wolniak, R.; Grebski, M.E.; Olkiewicz, A. Comparative analysis of the impact of the business incubator center on the economic sustainable development of regions in USA and Poland. Sustainability 2018, 11, 1-22. [CrossRef]

9. Mian, S.; Lamine, W.; Fayolle, A. Technology Business Incubation: An overview of the state of knowledge. Technovation 2016, 50, 1-12. [CrossRef]

10. Scaramuzzi, E. Incubators in Developing Countries: Status and Development Perspectives; The World Bank: Washington, DC, USA, 2002. 
11. Fernández, P.; Blanco, F.J.; Alonso, M.A.; Santos, M.; González-Blanch, J.M.; Romero, A.; González, L.; Berenguer, D. El Papel de los Viveros de Empresas en la Creación de Empleo; Universidad Rey Juan Carlos: Madrid, Spain, 2011.

12. Vaquero, A.; Ferreiro, F.J. Experiencias regionales en viveros de empresas. Rev. Estud. Reg. 2015, 102, 177-208.

13. Bruneel, J.; Ratinho, T.F.; Clarysse, B.; Groen, A.J. The Evolution of Business Incubators: Comparing demand and supply of business incubation services across different incubator generations. Technovation 2012, 32, 110-121. [CrossRef]

14. Martínez, A. Gestión y planificación de los parques tecnológicos. Econ. Ind. 1987, 258, 103-111.

15. Gatewood, B.; Ogden, L.; Hoy, F. Incubator Centers: Where they are and where are they going. In Proceedings of the V Congreso Anual Babson College Entrepreneurship Research, Wellesley, MD, USA, 1985.

16. Peterson, J. Creating Jobs by Creating Businesses: The Role of Business Incubators; National Council for Urban Economic Development: Washington, DC, USA, 1985.

17. Allen, D. An entrepreneurial marriage: Business incubators. In Proceedings of the V Congreso Anual Babson Collage Entrepreneurship Research, Wellesley, MD, USA, 1985.

18. COTEC. Conceptos Básicos de Referencia para el Estudio de la Innovación Tecnológica; Fundación COTEC: Madrid, Spain, 1993.

19. COTEC. Libro Blanco. El Sistema Español de Innovación. Diagnóstico y Recomendaciones; Fundación COTEC: Madrid, Spain, 2004.

20. Velasco, B. Incubadoras de Empresas, Incubadoras de Negocios. In Proceedings of the Memorias VI Seminario Latinoamericano de Gestión Tecnológica, Santiago de Chile, Chile, 14 July 1995; pp. 299-302.

21. Autio, E.; Klofsten, M. A comparative study of two European business incubators. J. Small Bus. Manag. 1998, $36,30-43$.

22. Eurobics (European Business and Innovation Centres). An Instrument to Assist Regional Development, European Union Regional Policy; European Commission: Brussels, Belgium, 2009.

23. Ferreiro, F.J.; Vaquero, A. El Papel de los Viveros de Empresa en Galicia Como Agentes de Promoción Económica y Generación de Empleo; Xunta de Galicia: Santiago de Compostela, Spain, 2010.

24. Perdomo Charry, G.; Arias, J.E.; Lozada, N.E. Business incubator research: A review and future directions. Pensam. Gest. 2014, 37, 41-65. [CrossRef]

25. Baciu, E.L.; Vîrgă, D.; Lazăr, T.A. What Characteristics Help Entrepreneurs 'Make It' Early on in Their Entrepreneurial Careers? Findings of a Regional Study from Romania. Sustainability 2020, 12, 1-27. [CrossRef]

26. Wolniak, R.; Grebski, M.E.; Skotnicka-Zasadzień, B. Comparative analysis of the level of satisfaction with the services received at the business incubators (Hazleton, PA, USA and Gliwice, Poland). Sustainability 2019, 11, 1-22. [CrossRef]

27. EBN (European Business and Innovation Centre Network). EC-BIC Observatory 2013 and the Last 3-Year Trends; European Bic Network: Brussels, Belgium, 2013.

28. Freeman, C. The Role of Technical Change in National Economic Development. In Technological Change, Industrial Restructuring and Regional Development; Amin, A., Goddard, J.B., Eds.; Allen and Unwin: London, UK, 1986; pp. 100-115. [CrossRef]

29. Formichella, M. La Evolución del Concepto de Innovación y su Relación con el Desarrollo; Beca de Iniciación del INTA, Gestión del Emprendimiento y la Innovación: Tres Arroyos, Argentina, 2005.

30. Gurrutxaga, A. Condiciones y condicionamientos de la innovación social. ARBOR Cienc. Pens. Cult. 2011, 187, 1045-1064. [CrossRef]

31. Mas, M.; Quesada, J. Las políticas de I+D+i ante la crisis. Rev. Galega Econ. 2010, 19, 1-17.

32. Van der Vrade, V.; Jong, J.; Vanhaverbeke, W. Open Innovation in SMEs: Trends, Motives and Management Challenges. Technovation 2009, 29, 423-437. [CrossRef]

33. Delgado, M.; Navas, J.E.; Martín, G.; López, P. La Innovación Tecnológica Desde el Marco del Capital Intelectual [Cuaderno de Trabajo 4]; Escuela Universitaria de Estadística: Madrid, Spain, 2008.

34. Escobar, V. La innovación Tecnológica. Medisan 2000, 4, 3-4.

35. Montoro, M.A. Comportamiento innovador. Un análisis de las empresas localizadas en la comunidad gallega. Rev. Galega Econ. 2010, 19, 1-19. 
36. Harmaakorpi, V.; Rinkinen, S. Regional development platform as incubators of business ecosystems. Case study: The Lahti urban region, Finland. Growth Chang. 2020, 51, 626-645. [CrossRef]

37. Öberg, C.; Alexander, A.T. The openness of open innovation in ecosystems-integrating innovation and management literature on knowledge linkages. J. Innov. Knowl. 2019, 4, 211-218. [CrossRef]

38. Ferreira, J.J.; Teixeira, A.A. Open innovation and knowledge for fostering business ecosystems. J. Innov. Knowl. 2019, 4, 253-255. [CrossRef]

39. Lange, G.S.; Johnston, W.J. The value of business accelerators and incubators-An entrepreneur's perspective. J. Bus. Ind. Mark. 2020. [CrossRef]

40. Rauter, R.; Globocnik, D.; Perl-Vorbach, E.; Baumgartner, R.J. Open innovation and its effects on economic and sustainability innovation performance. J. Innov. Knowl. 2019, 4, 226-233. [CrossRef]

41. Surana, K.; Singh, A.; Sagar, A. Strengthening science, technology, and innovation-based incubators to help achieve sustainable development goals: Lessons from India. Technol. Forecast. Soc. Chang. 2020, 157, 1-47. [CrossRef]

42. Fundación para el Análisis Estratégico y Desarrollo de la Pequeña y Mediana Empresa. Análisis Estratégico Para El Desarrollo De La PYME En España: Digitalización Y Responsabilidad Social; FAEDPYME (Fundación para el Análisis Estratégico y Desarrollo de la Pequeña y Mediana Empresa): Murcia, Spain, 2018.

43. CSR-CESGAR. VI Informe: La Financiación de la Pyme en España. Resultados de Marzo de 2018; Sociedades de Garantía Recíproca: Madrid, Spain, 2018.

44. Montégu, J.P.; Calvo, C.; Pertuze, J.A. Competition, R\&D and innovation in Chilean firms. Manag. Res. J. Iberoam. Acad. Manag. 2019, 17, 379-403. [CrossRef]

45. Lafuente, E.; Solano, A.; Leiva, J.C.; Mora-Esquivel, R. Determinants of innovation performance. Acad. Rev. Latinoam. Adm. 2019, 32, 40-62. [CrossRef]

46. Garnsey, E.; Stam, E.; Heffernan, P. New Firm Growth: Exploring Processes and Paths. Ind. Innov. 2006, 13, 1-20. [CrossRef]

47. Laitinen, E.K. Profitability Ratios in the Early Stages of a Startup. J. Entrepr. Finance 2017, 19, 1-28.

48. Colombo, M.G.; Delmastro, M. How effective are technology incubators? Evidence from Italy. Res. Policy 2002, 31, 1103-1122. [CrossRef]

49. Lukeš, M.; Zouhar, J. The causes of early-stage entrepreneurial discontinuance. Prague Econ. Pap. 2016, 25, 19-36. [CrossRef]

50. Henrekson, M.; Johansson, D. Gazelles as job creators: A survey and interpretation of the evidence. Small Bus. Econ. 2010, 35, 227-244. [CrossRef]

51. Haltiwanger, J.; Jarmin, R.S.; Miranda, J. Who creates jobs? Small versus large versus young. Rev. Econ. Stat. 2013, 95, 347-361. [CrossRef]

52. Coad, A.; Daunfeldt, S.O.; Hölzl, W.; Johansson, D.; Nightingale, P. High-growth firms: Introduction to the special section. Ind. Corp. Chang. 2014, 23, 91-112. [CrossRef]

53. Autio, E.; Rannikko, H. Retaining winners: Can policy boost high-growth entrepreneurship? Res. Policy 2016, 45, 42-55. [CrossRef]

54. Lerner, J. The future of public efforts to boost entrepreneurship and venture capital. Small Bus. Econ. 2010, 35, 255-264. [CrossRef]

55. Ferreiro, F.J.; Camino, M. Análisis cuantitativo de los centros de iniciativas empresariales medido a través del método de la balanza fiscal: El caso gallego. Rev. Galega Econ. 2016, 25, 61-75.

56. Dvouletý, O.; Longo, M.C.; Blažková, I.; Lukeš, M.; Andera, M. Are publicly funded Czech incubators effective? The comparison of performance of supported and nonsupported firms. Eur. J. Innov. Manag. 2018, 21, 543-563. [CrossRef]

57. Dvouletý, O.; Lukeš, M. Review of empirical studies on self-employment out of unemployment: Do self-employment policies make a positive impact? Int. Rev. Entrep. 2016, 14, 361-376.

58. Ferreiro-Seoane, F.J. Los viveros de empresas en Galicia: Una estrategia generadora de riqueza. Ph.D. Thesis, Universidad de A Coruña, A Coruña, Spain, 14 March 2013.

59. INE. Available online: https://www.ine.es/ (accessed on 22 October 2019).

60. Ferreiro-Seoane, F.J.; Mendoza, J.; Hernández, M. Contribution of the nurseries of Spanish companies in the labor market. Contad. Adm. 2018, 63,1-16. [CrossRef] 
61. Ferreiro-Seoane, F.J. Análisis de los viveros de empresas en Galicia según su orientación tecnológica o generalista. Cuad. Gest. 2015, 16, 49-74. [CrossRef]

62. Ferreiro-Seoane, F.J.; Del Campo, M.O.; Camino, M. Analysis of Business incubators in Galicia through the Integral Model of economic profitability. Investig. Reg. J. Reg. Res. 2015, 33, 7-31.

(C) 2020 by the authors. Licensee MDPI, Basel, Switzerland. This article is an open access article distributed under the terms and conditions of the Creative Commons Attribution (CC BY) license (http://creativecommons.org/licenses/by/4.0/). 